\title{
Choledochal cyst in the pediatric population: experience of 13 laparoscopic procedures in two years at a single institution
}

\section{Cisto de colédoco na população pediátrica: experiência de 13 procedimentos laparoscópicos em dois anos de uma única instituição}

Carolina Talini'; Bruna Cecília Neves de-Carvalho'; Letícia Alves Antunes'; Claudio Schulz'; Cesar Cavalli Sabbaga1; Sylvio Gilberto Andrade Avilla ${ }^{1}$; João Carlos Garbers ${ }^{1}$; Luiz Roberto Farion de-Aguiar'; leilla Grisa Telles'; Giovana Camargo de-Almeida'; Fernando Antonio Bersani Amado'; Elisangela de Mattos e-Silva, ACBC-PR¹

\section{A B S T R A C T}

\begin{abstract}
Objective: to describe the first 13 cases of laparoscopic correction of common bile duct cyst in the Pequeno Principe Hospital, Curitiba, Paraná, Brazil. Methods: we performed a retrospective analysis of medical records of cases of choledochal cyst operated by laparoscopy between March 2014 and September 2016. Results: of the 13 patients, eight were female and the mean age at surgery was 7.8 years. The most common symptom was abdominal pain. The hepaticoduodenal anastomosis was the most used reconstruction technique, in $84.6 \%$ of the cases. There was no conversion to laparotomy or intraoperative complications. Only one patient presented anastomotic fistula and was reoperated by laparotomy. All patients were followed up in an outpatient clinic, were asymptomatic and had no episode of cholangitis after surgery, with a mean follow-up of 16 months. Conclusion: laparoscopy is a safe method to correct choledochal cysts, even in younger children, with low rates of complications and low rates of conversion to open surgery when performed by well trained surgeons.
\end{abstract}

Keywords: Pediatrics. Choledochal Cyst. Laparoscopy. Anastomosis, Roux-en-Y. Anastomosis, Surgical.

\section{INTRODUCTION}

C holedochal cysts are rare anomalies of the bile ducts?' characterized by disproportionate dilatation of the biliary ductal system². They were initially described by Vater, in 1723, and classified by Todani et al. ${ }^{3}$, in 1977. It is estimated that the overall incidence is one in every 150,000 live births, with a female predominance of $4: 1^{1}$. They may manifest only in adulthood, but about $60 \%$ of cases are diagnosed in the first decade of life $^{4}$. There are several etiological explanations, but the most accepted is the Babbitt Theory, which attributes the formation of the cysts to an abnormality at the junction of the pancreatic duct with the common bile duct, outside the Vater ampulla, resulting in a common long canal, which allows the reflux of pancreatic juice into the bile duct ${ }^{5}$. The active pancreatic enzymes provoke inflammation and weakness of the walls of the bile duct, leading to the formation of the cysts. Patients with extensive dilatations of the biliary tract have a predisposition to biliary stasis, leading to recurrent cholangitis, calculus formation and, ultimately, secondary biliary cirrhosis and malgyn transformation ${ }^{5}$. Complete cyst excision is the best treatment strategy and involves complete resection of the cyst associated with bile duct reconstruction ${ }^{6}$. From the first report, by Farello et al. ${ }^{7}$, in 1995, laparoscopic excision of cysts with Roux-en-Y and hepaticojejunal anastomosis reconstruction in children has gained worldwide attention ${ }^{8}$.

The objective of this study was to describe the 
first 13 cases of laparoscopic correction of congenital dilatation of the biliary tract in our institution during a period of two years, to discuss its results and to carry out a review of the literature.

\section{METHODS}

We performed a retrospective evaluation of the medical records of patients submitted to laparoscopic choledochal cyst treatment between March 2014 and September 2016. We used a standardized questionnaire to collect data the following data: name, gender, age at diagnosis, age at time of surgery, episodes of pancreatitis prior to treatment, symptoms, imaging and classification of Todani, surgical technique chosen, intraoperative and postoperative complications, hospitalization time, follow-up, and postoperative symptoms. We tabulated the data in a Excel ${ }^{\circledR}$ spreadsheet for descriptive analysis.

The research was previously approved by the Ethics Committee of the Institution, with CAAE opinion: 58448116.3.0000.0097.

\section{RESULTS}

During the study period, 13 laparoscopic choledochal cyst resections were performed. Eight $(61.5 \%)$ patients were female and five $(38.5 \%)$ were male. The mean age at diagnosis was 6.4 years (ranging from two months to 11.4 years) and, at the time of surgery, it was 7.8 years (ranging from two months to 14.3 years). Regarding the episodes of pancreatitis, $53.8 \%$ of the patients $(7 / 13)$ presented acute pancreatitis prior to the etiological diagnosis. Abdominal pain was the most frequent clinical manifestation, as described in table 1.
Table 1. Clinical picture

\begin{tabular}{ccc}
\hline Symptoms & $\begin{array}{c}\text { Number of } \\
\text { patients }\end{array}$ & $\%$ \\
\hline Abdominal pain & $12 / 13$ & $92.3 \%$ \\
Jaundice & $6 / 13$ & $46.1 \%$ \\
Vomiting & $2 / 13$ & $15.3 \%$ \\
Fever & $1 / 13$ & $7.7 \%$ \\
\hline
\end{tabular}

Table 2 shows data for each patient.

The diagnosis was confirmed by ultrasonography and magnetic resonance cholangiopancreatography in all patients. In cases of acute pancreatitis, hepatic function and amylase tests were performed to evaluate clinical and laboratory improvement. Hepaticoduodenal anastomosis was the most commonly performed biliary reconstruction procedure in $84.6 \%$ of the cases. There was no conversion to laparotomy or intraoperative complications. All patients underwent drainage of the abdominal cavity with a suction drain for a mean period of 6.7 days and the mean time of hospitalization was 7.7 days (ranging from five to 26 days). One patient presented biliary fistula and was reoperated by laparotomy on the ninth day after the first surgery to reinforce the anastomosis. This patient had a history of more than one episode of preoperative pancreatitis and presented large amounts of adhesions and friable tissues in the first procedure.

All patients remained in outpatient follow-up, were asymptomatic and did not present postoperative cholangitis, with an average follow-up of 16 months (ranging from eight months to 2.6 years). One patient developed vomiting and abdominal pain after surgery. Upper gastrointestinal endoscopy demonstrated positive Helicobacter pylori gastritis and the patient displayed clinical improvement after treatment. 
Table 2. Patients' characteristics.

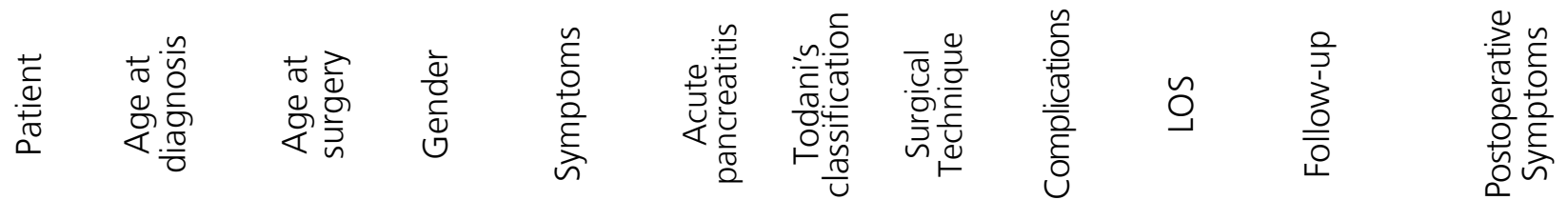

\begin{tabular}{|c|c|c|c|c|c|c|c|c|c|c|c|}
\hline 1 & 7 years & $\begin{array}{l}10.8 \\
\text { years }\end{array}$ & M & $\begin{array}{c}\text { Pain + } \\
\text { jaundice }\end{array}$ & No & 1 & $\mathrm{HJ}$ & None & $\begin{array}{c}8 \\
\text { days }\end{array}$ & $\begin{array}{c}2.6 \\
\text { years }\end{array}$ & Asymptomatic \\
\hline 2 & $\begin{array}{c}5 \\
\text { months } \\
\text { ago }\end{array}$ & $\begin{array}{c}7 \\
\text { months } \\
\text { ago }\end{array}$ & M & Pain & No & 1 & $\mathrm{HJ}$ & None & $\begin{array}{c}6 \\
\text { days }\end{array}$ & $\begin{array}{c}2.6 \\
\text { years }\end{array}$ & Asymptomatic \\
\hline 3 & $\begin{array}{c}7.1 \\
\text { years }\end{array}$ & $\begin{array}{l}7.2 \\
\text { years }\end{array}$ & $\mathrm{F}$ & Pain & No & I & $H D$ & None & $\begin{array}{c}5 \\
\text { days }\end{array}$ & 2 years & Asymptomatic \\
\hline 4 & $\begin{array}{l}7.3 \\
\text { years }\end{array}$ & $\begin{array}{l}7.4 \\
\text { years }\end{array}$ & $\mathrm{M}$ & $\begin{array}{c}\text { Pain, } \\
\text { jaundice, } \\
\text { fever } \\
\text { and } \\
\text { vomiting }\end{array}$ & Yes & 1 & $H D$ & $\begin{array}{l}\text { Biliary } \\
\text { fistula }\end{array}$ & $\begin{array}{l}26 \\
\text { days }\end{array}$ & $\begin{array}{c}1.9 \\
\text { years }\end{array}$ & Asymptomatic \\
\hline 5 & $\begin{array}{c}4.6 \\
\text { years }\end{array}$ & $\begin{array}{l}4.7 \\
\text { years }\end{array}$ & $\mathrm{F}$ & $\begin{array}{c}\text { Pain + } \\
\text { jaundice }\end{array}$ & No & I & $H D$ & None & $\begin{array}{c}6 \\
\text { days }\end{array}$ & $\begin{array}{c}1.8 \\
\text { years }\end{array}$ & Asymptomatic \\
\hline 6 & 8 years & 9 years & M & Pain & Yes & 1 & $H D$ & None & $\begin{array}{c}6 \\
\text { days }\end{array}$ & $\begin{array}{c}1.7 \\
\text { years }\end{array}$ & Asymptomatic \\
\hline 7 & $\begin{array}{c}6.6 \\
\text { years }\end{array}$ & $\begin{array}{l}6.7 \\
\text { years }\end{array}$ & $\mathrm{F}$ & $\begin{array}{c}\text { Pain }+ \\
\text { vomiting }\end{array}$ & Yes & I & $\mathrm{HD}$ & None & $\begin{array}{c}6 \\
\text { days }\end{array}$ & $\begin{array}{c}1.6 \\
\text { years }\end{array}$ & $\begin{array}{l}\text { UGIE: } \\
\text { H. pylori + }\end{array}$ \\
\hline 8 & $\begin{array}{c}2 \\
\text { months }\end{array}$ & $\begin{array}{c}2 \\
\text { months }\end{array}$ & $\mathrm{F}$ & Icterícia & No & I & $H D$ & None & $\begin{array}{c}6 \\
\text { days }\end{array}$ & $\begin{array}{c}1.3 \\
\text { years }\end{array}$ & Asymptomatic \\
\hline 9 & $\begin{array}{c}9.4 \\
\text { years }\end{array}$ & $\begin{array}{c}9.5 \\
\text { years }\end{array}$ & $\mathrm{F}$ & $\begin{array}{c}\text { Pain + } \\
\text { vomiting }\end{array}$ & Yes & 1 & $H D$ & None & $\begin{array}{c}6 \\
\text { days }\end{array}$ & $\begin{array}{c}1.1 \\
\text { years }\end{array}$ & Asymptomatic \\
\hline 10 & $\begin{array}{l}11.4 \\
\text { years }\end{array}$ & $\begin{array}{l}12.4 \\
\text { years }\end{array}$ & $\mathrm{F}$ & Pain & Yes & I & $\mathrm{HD}$ & None & $\begin{array}{c}5 \\
\text { days }\end{array}$ & $\begin{array}{c}10 \\
\text { months }\end{array}$ & Asymptomatic \\
\hline 11 & $\begin{array}{l}7.3 \\
\text { years }\end{array}$ & $\begin{array}{c}8.5 \\
\text { years }\end{array}$ & M & $\begin{array}{c}\text { Pain + } \\
\text { jaundice }\end{array}$ & Yes & IV & $H D$ & None & $\begin{array}{c}5 \\
\text { days }\end{array}$ & $\begin{array}{c}9 \\
\text { months }\end{array}$ & Asymptomatic \\
\hline 12 & 4 years & $\begin{array}{l}14.3 \\
\text { years }\end{array}$ & $\mathrm{F}$ & Pain & No & IV & $H D$ & None & $\begin{array}{c}5 \\
\text { days }\end{array}$ & $\begin{array}{c}8 \\
\text { months }\end{array}$ & Asymptomatic \\
\hline 13 & $\begin{array}{l}10.3 \\
\text { years }\end{array}$ & $\begin{array}{l}10.4 \\
\text { years }\end{array}$ & $\mathrm{F}$ & $\begin{array}{c}\text { Pain, } \\
\text { jaundice } \\
\text { and } \\
\text { fever }\end{array}$ & Yes & 1 & $H D$ & None & $\begin{array}{c}6 \\
\text { days }\end{array}$ & $\begin{array}{c}8 \\
\text { months }\end{array}$ & Asymptomatic \\
\hline
\end{tabular}

M: Male; F: Female; HJ: Hepaticojejunal anastomosis; HD: Hepaticoduodenal anastomosis; LOS: Length of Stay; UGIE: Upper gastrointestinal endoscopy. 


\section{DISCUSSION}

Congenital biliary dilatation represents a diagnostic and therapeutic challenge for pediatric surgeons, requiring a high degree of suspicion and efficient etiological investigation for the correct diagnosis and appropriate treatment ${ }^{4}$. About $80 \%$ of the patients become symptomatic in childhood $^{9}$ and the most common symptoms are abdominal pain, in about $60 \%$ of cases, jaundice, in $80 \%$ and vomiting, in about $44 \%{ }^{6}$. The classic triad of jaundice, abdominal pain and palpable mass is found in only $20 \%$ of patients, predominantly in the pediatric age group 1 . The patients in this series were predominantly female $(61.5 \%)$, but in proportions not as superior as those reported in the literature, 4:1 for the female gender. Regarding symptoms, most of them presented pain (92.3\%) and jaundice (46.1\%) as described in the literature, but no patient presented the classic triad. Todani's classification is still the most accepted and used throughout the world (Figure 1) ${ }^{10}$. According to the literature, the most common form in children is type I, in up to $75 \%$ of cases, as found in this series, followed by type IV, in about $19 \%$ of cases $^{2}$.

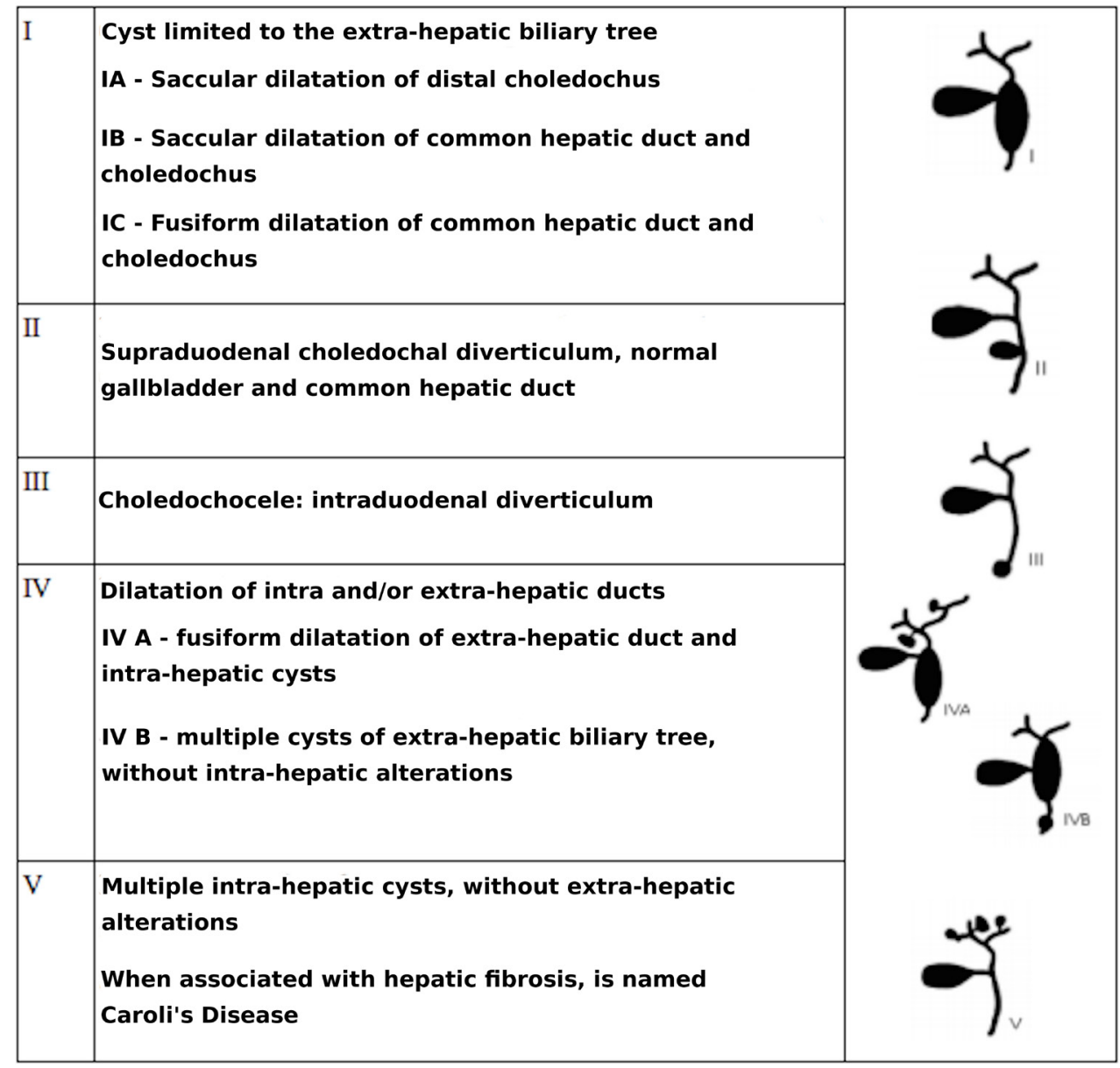

Figure 1. Todani classification (1977) for bile duct cysts.

Currently, the investigation begins with ultrasonography, which presents high sensitivity for diagnosis of diseases of the biliary tract ${ }^{4}$. Prenatal diagnosis has been described, in some cases, as of the 15th week of gestation and has become increasingly frequent in our environment ${ }^{2}$. In this series only one patient received prenatal diagnosis. Noninvasive tests to define the anatomy of the biliary tree include computed tomography (sensitivity and specificity of about 90\%), hepatic-biliary scintigraphy with technetium-99 and magnetic resonance imaging (70 to $100 \%$ sensitivity and 90 to $100 \%$ specificity). All these methods can be used as a diagnostic approach, magnetic resonance imaging being the gold standard ${ }^{1,4}$. All patients in this sample were 
submitted to ultrasonography and magnetic resonance imaging for diagnostic confirmation.

After diagnostic confirmation, the treatment of choice is surgical and consists of a complete resection of the cyst accompanied by reconstruction with a biliodigestive anastomosis. Regarding the laparoscopic approach, the main advantages include excellent visualization and lower blood loss ${ }^{11}$, as well as better postoperative recovery, less surgical trauma, less postoperative pain, less trauma to the abdominal wall, shorter drainage time of the cavity, reduction of postoperative paralytic ileus time and shorter hospitalization time. General complications and mortality rates are also lower compared with the series of patients treated by open surgery ${ }^{12,13}$. The surgical approach consists of the complete removal of the cyst associated with the reconstruction of the biliary tree through a bilioenteric anastomosis. Although hepaticojejunostomy has been considered the gold standard for many years, hepaticoduodenostomy has been gaining more and more adherents and has been preferred by many surgeons who claim shorter operative time, less chances of postoperative adhesions, shorter hospitalization time, lower incidence of anastomotic fistulas, and also greater ease of endoscopic dilatation in case of anastomosis stenosis ${ }^{5}$. The majority of patients in this series underwent reconstruction by hepaticoduodenal anastomosis. Only the first two patients were submitted to hepaticojejunostomy.

Another controversial issue regarding treatment concerns the drainage of the abdominal cavity. Recent studies have demonstrated some aspects of drainage, such as severe infections and narrowing of the common hepatic duct ${ }^{14}$. However, surgeons who opt for drainage do so in order to early diagnose possible biliary fistulas. In this series all patients were submitted to drainage of the abdominal cavity. No patient presented complications related to drainage and there was one case of biliary fistula, that was diagnosed early due to the use of the drain. In addition to biliary fistula, described in the literature as present in up to $10 \%$ of patients, other postoperative complications may occur, but they are uncommon, such as dehiscence of the anastomosis, cholangitis, pancreatitis, intestinal obstruction due to adhesions and surgical wound infection ${ }^{15}$.

Regarding follow-up, some studies have shown that even patients with prenatal diagnosis and surgery in the first year of life present changes in liver biopsies as a result of biliary obstruction, with ductal proliferation, fibrosis and even cirrhosis ${ }^{4}$. Malignant alterations of the bile duct epithelium may occur even after removal of the cyst and, therefore, patients need to be followed and observed for symptoms' recurrence. Some of these malignant transformations have been seen even in areas distant from the original cyst. Common sites for the development of malignancies are the bile duct (50\%), the gallbladder in nonoperated patients (43\%), and the peri-ampullary region $(2.5 \%)^{2}$. During the follow-up period the patients in this sample did not present additional complications, symptoms' recurrence or signs of malignancy.

The results obtained in our series are comparable to the ones presented in the literature, confirming that laparoscopic choledochal cyst repair is feasible, even in young children, with low rates of complication and conversion to laparotomy when performed by experienced and well-trained surgeons. Hepaticoduodenal anastomosis has become the technique of choice for many surgeons in this team, since it provides easier anastomosis, shorter surgical and hospitalization time, and low complications in the mid-term follow-up.

\section{R E S U M O}

Objetivo: descrever os primeiros 13 casos de correção laparoscópica de cisto do ducto biliar comum no Hospital Pequeno Príncipe, Curitiba, Paraná, Brasil. Métodos: análise retrospectiva dos registros médicos em prontuário dos casos de cisto de colédoco operados por via laparoscópica entre março de 2014 e setembro de 2016. Resultados: dos 13 pacientes, oito eram do sexo feminino e a média de idade na ocasião da cirurgia foi de 7,8 anos. O sintoma mais comum foi dor abdominal. A anastomose hepático-duodenal foi a técnica de reconstrução mais utilizada, em $84,6 \%$ dos casos. Não houve conversão para laparotomia ou complicações intraoperatórias. Apenas um paciente apresentou fístula da anastomose e foi reoperado por laparotomia. Todos permanecem em acompanhamento ambulatorial, com tempo de seguimento médio de 16 meses, assintomáticos e não apresentaram episódio de colangite após a cirurgia. Conclusão: a laparoscopia é um método seguro para correção dos cistos de colédoco, mesmo em crianças mais jovens, com baixas taxas de complicações e baixas taxas de conversão para cirurgia aberta quando realizada por cirurgiões com bom treinamento.

Descritores: Pediatria. Cisto do Colédoco. Laparoscopia. Anastomose em-Y de Roux. Anastomose Cirúrgica. 


\section{REFERENCES}

1. Silva-Baez H, Coello-Ramírez $\mathrm{P}$, Ixtabalán-Escalante EM, Sotelo-Anaya E, Gallo-Morales M, CorderoEstrada $\mathrm{E}$, et al. Treatment of choledochal cyst in a pediatric population. A single institution experience of 15-years. Case series. Ann Med Surg (Lond). 2015;5:81-5.

2. Subramony R, Kittisarapong N, Barata I, Nelson M. Choledochal cyst mimicking gallbladder with stones in a six-year-old with right-sided abdominal pain. West J Emerg Med. 2015;16(4):568-71.

3. Todani T, Watanabe $Y$, Narusue $M$, Tabuchi $K$, Okajima K. Congenital bile duct cysts: classification, operative procedures, and review of thirty-seven cases including cancer arising from choledochal cyst. Am J Surg.1977;134(2):263-9.

4. Forny DN, Ferrante SM, Silveira VG, Siviero I, Chagas VL, Méio IB. Choledochal cyst in childhood: review of 30 cases. Rev Col Bras Cir. 2014;41(5):331-5.

5. Gezer HÖ, O uzkurt P, Temiz A, nnce E, Ezer SS, Hiçsönmez A. Choledochal cyst in children: intrahepatic ductal dilatation does not indicate true intrahepatic biliary duct disease. Turk J Gastroenterol. 2016;27(1):23-9.

6. Gadelhak N, Shehta A. Hamed H. Diagnosis and management of choledochal cyst: 20 years of single center experience. World J Gastroenterol. 2014;20(22):7061-6.

7. Farello $G A$, Cerofolini $A$, Rebonato $M$, Bergamaschi G, Ferrari C, Chiappetta A. Congenital choledochal cyst: video-guided laparoscopic treatment. Surg Laparosc Endosc. 1995;5(5):354-8.

8. Lee JH, Kim SH, Kim HY, Choi YH, Jung SE, Park $\mathrm{KW}$. Early experience of laparoscopic choledochal cyst excision in children. J Korean Surg Soc. 2013;85(5):225-9.

9. Yurttutan N, Karakus SC, Koku N, Demirci M, Ucak
R. A giant choledochal cyst in infancy: a case report. Korean J Pediatr. 2016;59(5):239-41.

10. Tongprasert F, Traisrislp K, Tongsong T. Prenatal diagnosis of choledochal cyst: a case report. J Clin Ultrasound. 2012;40(1):48-50.

11. Liuming $H$, Hongwu $Z$, Gang $L$, Jun J, Wenying $H$, Wong KK, et al. The effect of laparoscopic excision vs open excision in children with choledochal cyst: a midterm follow-up study. J Ped Surg. 2011;46(4):6625.

12. Liem NT, Pham HD, Vu HM. Is the laparoscopic operation as safe as open operation for choledochal cyst in children? J Laparoendosc Adv Surg Tech A. 2011;21(4):367-70.

13. Wang B, Feng Q, Mao JX, Liu L, Wong KK. Early experience with laparoscopic excision of choledochal cyst in 41 children. J Ped Surg. 2012;47(12):2175-8.

14. Diao M, Li L, Cheng W. To drain or not to drain in Roux-en-Y hepaticojejunostomy for children with choledochal cysts in the laparoscopic era: a prospective randomized study. J Ped Surg. 2012;47(8):1485-9.

15. Cherqaoui A, Haddad M, Roman C, Gorincour G, Marti J, Bonnard A, et al. Management of choledochal cyst: evolution with antenatal diagnosis and laparoscopic approach. J Minim Access Surg. 2012;8(4):129-33.

Received in: 02/03/2018

Accepted for publication: 22/03/2018

Conflict of interest: none.

Source of funding: none.

\section{Mailing address:}

Carolina Talini

E-mail: caroltalini@yahoo.com.br /

fbersani.amado@gmail.com

(cc) BY 